\title{
ENTREVISTA COM SONIA NETTO SALOMÃO
}

\section{INTERVIEW WITH SONIA NETTO SALOMÃO}

\author{
Andréia Guerini \\ Universidade Federal de Santa Catarina/CNPq \\ Florianópolis, Santa Catarina, Brasil
}

\begin{abstract}
Sonia NetTo SAlomão é titular de Língua e Tradução Portuguesa e Brasileira na Sapienza, Universidade de Roma 1. É Doutora em Teoria da Literatura pela UFRJ, com pós-doutorado em História literária e Filologia pela Sapienza. Foi professora da UFRJ e da UERJ. Atualmente é também titular da Cátedra "Antônio Vieira" da Sapienza/Instituto Camões de Lisboa e VicePresidente da AISPEB (Associação Italiana de Estudos Portugueses e Brasileiros); pertence a várias instituições na Itália e no exterior. Coordena a coleção LusoBrasiliana (Editora Nuova Cultura, Roma) e acordos internacionais de cooperação científica e cultural com universidades brasileiras e portuguesas. Possui mais de 100 títulos publicados, 15 volumes individuais e 11 volumes coletivos, artigos e ensaios, dedicados aos temas da censura, da literatura popular, do barroco de Antônio Vieira e aos seus inéditos, da narrativa brasileira e portuguesa, do oitocentos de Machado de Assis e de Eça de Queirós, do novecentos de Guimarães Rosa, Carlos Drummond de Andrade e Clarice Lispector. Nos últimos anos tem-se dedicado à história da língua portuguesa e aos problemas teóricos da tradução. Entre os seus últimos trabalhos, Traduzione, tradizioni (Costellazioni, 7, 2018) e Machado de Assis e o cânone ocidental: itinerários de leitura (Prêmio Jabuti de 2017).
\end{abstract}


Revista da Anpoll (RA): Como nasceu a ideia do livro. Tendo em vista que a critica sobre a obra de Machado de Assis é bastante ampla, quais foram os principais desafios para a composição do livro?

Sonia Netto Salomão (SNS): Este livro nasceu lentamente e possui três eixos de investigação: o primeiro parte da experiência com os cursos de tradução na Itália, quando examinei várias versões, avaliando o modo como Machado foi traduzido e recebido. É surpreendente constatar que ele foi traduzido desde 1928 (Memórias póstumas de Brás Cubas), embora Dom Casmurro já tivesse sido traduzido em São Paulo em 1914 por Antonio Piccarollo (jornalista e político fundador do Partido Socialista Italiano e, na cidade paulista, de inúmeros jornais, figurando também como um dos fundadores da Faculdade de Letras e Filosofia, onde ensinou Sociologia). Personagem este que, por si só, nos dá a dimensão da presença italiana e do seu intercâmbio com a cultura brasileira. Percebi, também, em cursos específicos de tradução, que Machado estava entre os mais preparados tradutores de língua portuguesa para a versão de Dante, feita por ele em tercetos, quando na época se traduzia só em prosa; e que ele conhecia muito bem Leopardi ao qual teria chegado pelo estudo da sátira menipeia e de Luciano, em particular, cujas sátiras eram igualmente apreciadas pelo poeta italiano. Aqui abriu-se todo um capítulo ao qual dediquei 200 páginas e que fala, também, de como Machado incorporou temas da literatura e da ópera italiana, por exemplo. Este capítulo concentra muito trabalho de pesquisa inédita e de elaboração teórica.

Mas, na verdade, havia uma "família" alargada de escritores frequentada por Machado, muitos dos quais já tratados em estudos específicos em vários trabalhos de outros estudiosos. Neste segundo eixo, que constitui o primeiro capítulo do livro, o meu interesse era o de analisar o método de trabalho de Machado. Compreender como a análise crítica se somava ao ludismo dos seus textos; perceber por que Machado era tão particular e, ao mesmo tempo, universal, e porque ele desafiava o crítico ou a crítica, com aquela estratégia do jogador que envolve o seu parceiro de jogo, principalmente quando blefa. Daqui nasceu o título do livro; ou seja, da compreensão que Machado enfrentou vários modelos canônicos, dialogando com eles, num processo de aceitação, rejeição, reescritura, e assim por diante. Ele mesmo se define um "ruminante" e, desse modo, não há como não perceber um processo antropofágico, como o detectado pelos modernistas brasileiros, e que, no fim, identifica a nossa cultura póscolonial.

Realizando a experiência maravilhosa de ler os textos que Machado conheceu, examinando, como ele, os vários modelos, cheguei a uma carta do Pseudo Hipócrates com todos os ingredientes do "Alienista" e do seu riso de Demócrito. Com Vieira, eu havia enfrentado as "Lágrimas de Heráclito" ( S. Paulo, Ed. 34, 2001); com Machado, enfrentei o outro elemento de um antigo topos. Este o terceiro eixo de leitura, o da ironia, que inclui a língua literária de Machado, muito esquecida, e que se deve examinar de acordo com o projeto estético do autor de Dom Casmurro. O diálogo com a tradição crítica machadiana faz parte da própria construção deste livro. Como afirmei na Introdução: «O zigue-zague narrativo da obra machadiana provocou um zigue-zague crítico. Os 
capítulos aqui elencados se entrecruzam e dialogam entre si porque fazem parte de um todo articulado pela relação obra-crítica».

RA: Na introdução ao livro, você diz que nos últimos 15 anos existe uma "machadomania", como se Machado tivesse virado uma moda. Você poderia explicar melhor o que entende por "machodomania" e onde ela estaria localizada?

SNS: Na verdade, os meios de comunicação eletrônica, com os seus blogs, as suas emotions, funcionam como uma caixa de ressonância para todos os grandes autores que passaram a ser estudados a partir de facetas inesperadas, como é o caso de livros realizados sobre a gastronomia dos personagens de Eça de Queirós, por exemplo. Para Machado, principalmente em torno ao centenário de 2008, a questão não é diferente. Em âmbito acadêmico, por outro lado, se um determinado crítico salienta um elemento, como poderia ser o desdobramento do narrador, ou a leitura da sátira menipeia, um número infindável de estudos se multiplica, muitos dos quais, com pouca contribuição crítica, infelizmente. Todavia, como se fosse um "dever" falar de certo aspecto comentado por algum crítico renomado. Relacionei essa perspectiva ao capítulo «O senão do livro», do Memórias póstumas de Brás Cubas em que Machado já detectara tal fenômeno, com a caricatura do bibliômano, num processo até de auto-ironia, uma vez que ele também era um devorador de modas; só que sabia absorvê-las, modelá-las, transformá-las em alguma coisa de seu. Esse tipo de crítica homologadora foi condenada por Machado na charada deste capítulo que comentei. Outro problema é o do pouco aprofundamento das fontes. Cita-se apenas o que se leu por último, esquecendo-se de toda uma tradição crítica muito importante que tentei resgatar, dialogando com ela.

RA: Na terceira parte do seu livro, você se debruça a esmiuçar a relação de Machado com o sistema literário e cultural italiano. O que ainda precisa ser feito, estudado de Machado na Itália, já que você mesma afirma que "a relação de Machado de Assis com a cultura italiana ainda não foi estudada de forma abrangente e sistemática”?

SNS: Como já tive a oportunidade de observar, Machado se confrontou com os principais nomes da cultura italiana e estudou a história romana de modo aprofundado. Nas traduções que foram feitas na Itália é interessante notar nos prefácios como os tradutores identificaram os autores europeus presentes na obra machadiana. Lá estão franceses, ingleses e alemães, mas também autores gregos e latinos bem conhecidos na Itália.

Machado acompanhou e viveu a presença italiana no Rio de Janeiro: no teatro, na ópera, nos jornais, nos movimentos de independência e de instauração da República na Itália. Cavour é citado mais de uma vez na obra machadiana como símbolo de obstinação, como no capítulo IV das Memórias póstumas, «Uma ideia fixa», em que o nosso autor busca exemplos humorísticos para sustentar a sua tese: "Deus te livre, leitor, de uma ideia fixa; antes um argueiro, antes uma trave no olho. Vê o Cavour; foi a ideia fixa da unidade italiana que o matou". Na ocasião do acordo levado adiante por Cavour com a França, contra o 
domínio austríaco no norte da Itália, Machado escreve no «Correio Mercantil», em 10 de fevereiro de 1859, o poema À Itália. Em 25 de novembro de 1861, numa crônica do «Diário do Rio de Janeiro», sob o pseudônimo de Gil, o escritor carioca elogia o governo brasileiro por ter reconhecido sem delongas a unificação da Itália e demonstra conhecimento de causa, na sua exposição. Não resta dúvida que Machado estava inserido também no contexto em que as revistas, pelo seu caráter mais popular de divulgação, inclusive em função das ilustrações que pouco a pouco passavam a fazer parte integrante da edição, contribuíam para a veiculação da imagem de um novo país, graças às conquistas técnicas, também. Os italianos colaboraram com a tradição da caricatura, da crítica política e do humor. Nesse espaço, a literatura foi divulgada por meio das resenhas e da publicação, em forma de folhetim, de obras que seriam, a seguir, editadas em livro.

Por outro lado, um estudioso do porte de Ruggero Jacobbi deixou, em 1961 (Teatro in Brasile), importante depoimento sobre machado de Assis:

Talvez os italianos não saibam ainda que o escritor verdadeiramente universal produzido pelo Brasil em toda a sua história é Joaquim Maria Machado de Assis, o qual não é apenas um dos cinco ou seis pontos mais altos atingidos ao longo da literatura de língua portuguesa, mas é o único narrador sulamericano cujas obras maiores poderiam estar tranquilamente na mesma prateleira em que se conservam Stendhal, e Nievo, Gogol e Defoe, Merimée e Manzoni.

A partir dessas observações, há uma infinidade de temas a serem desenvolvidos: teatro, personagens políticos, meios de comunicação, como jornais italianos que circulavam no período, para não falar da ópera.

RA: Você acharia viável e factivel se pensar em um projeto de tradução integral da obra de Machado na Itália, tendo em vista as múltiplas relações do autor brasileiro com a cultura italiana?

SNS: Acho que este é um passo necessário, eu diria, para a afirmação de Machado a nível internacional e este tema será proposto numa próxima reunião, em 2020, no âmbito do Seminário Internacional Permanente Machado de Assis que criei na Sapienza, Universidade de Roma, há alguns anos.

RA: Você afirma que Machado de Assis tinha um acervo razoável de volumes em língua italiana, que contava com autores como Alfieri, De Amicis, Ariosto, Guicciardini, Leopardi, Tasso, Varchi, Dante e provavelmente Petrarca, Boccaccio e Ariosto. E em tradução francesa: Machiavelli, Manzoni, estudos de história e de crítica literária italiana sobre Dante e ainda os contemporâneos: Giosué Carducci, Cesare Cantù, Cesare Lombroso e Paolo Mantegazza. Você continua afirmando que entre os poetas que Machado mais admirava e que mais utilizou na construção de sua obra estão Leopardi e Tasso. Como você explicaria essa relação, por que essa relação não foi tão profunda com Dante, de quem Machado chegou inclusive a traduzir um Canto? 
SNS: Antes de mais nada, a relação com Dante é muito profunda e presente durante quarenta anos ininterruptos de citações de diversas obras do grande poeta. Ela é parte do que tenho chamado de "filigranas machadianas". Elas se desenham em baixo relevo e só com um paciente trabalho de pesquisa afloram. Como observei no capítulo 2.1, $O$ gênero e o modelo como reconhecimento, «o que desejo ressaltar é o método que ele aprende e admira não só em Luciano, mas também em outros autores como Dante, por exemplo. Machado está bem atento aos processos por meio dos quais esses grandes autores se relacionaram com o cânone clássico». Por esse mesmo motivo, ele percebe o niilismo de Leopardi. O «Dialogo della natura e di un'Anima» e o «Dialogo della natura e di un Islandese», escritos de 1824 a 1832, aproximadamente, fazem parte de uma mudança de perspectiva de Leopardi que passa a declarar, a partir de 1819, o desejo de mudar a sua perspectiva, passando a escrever "diálogos satíricos à maneira de Luciano". As raízes da sátira menipeia, portanto, pertencem tanto a Leopardi como a Machado. Para o grande poeta italiano, o projeto de fazer falar animais ou personagens mortos objetivava não só a busca de um novo estilo, como também de um novo projeto cultural. As Operette Morali assinalam uma mudança fundamental no pensamento leopardiano, que passa de um pessimismo sensitivo e existencial a um pessimismo radicalmente material e cósmico.

Quanto a Torquato Tasso, diz muito a anedota de uma sessão solene da Academia Brasileira de Letras, em 1905, para a entrega do ramo de um velho carvalho do Convento de Santo Onofre, em Roma, na sombra do qual Tasso amava repousar, e que foi remetido por Joaquim Nabuco da Itália para o ilustre amigo. Além de poesia épica, Tasso também escreveu poesias líricas que expressavam o seu conflito íntimo entre a religiosidade e uma flagrante sensualidade. Esse mesmo dilema entre o ser e o parecer marcou a vida e a obra de Machado de Assis. Portanto, eu não estabeleceria uma hierarquia, mas chamaria a atenção para o peso destes artistas. Leopardi, por sinal, é autor que está na moda, contemporaneamente, descoberto pela ecocriticism de raízes anglosaxônicas.

RA: Você afirma que muito do que Machado aprendeu sobre a Itália se deu através do olhar de Stendhal "Uma primeira constatação parece-nos importante fazer: a de que muito do que Machado aprendeu sobre a Itália o fez através do olhar histórico, cultural e anedótico de Stendhal, nos eruditos volumes que o escritor francês dedicou à terra de Dante”. O mesmo não se poderia afirmar da Itália em relação a Machado, isto é: Machado não teria chegado na Itália via a França, autores franceses?

SNS: Para responder a esta pergunta teríamos que abrir um capítulo sobre a relação centro-periferia, o papel das traduções, e assim por diante. Como salientei no ensaio em questão, a França ditava as regras, mas Machado pôde escolher outros modelos. Por quê? Aqui não há como ignorar - repito - a lacuna dos estudos sobre a presença italiana no Brasil, a partir da imperatriz que reinou durante 40 anos. Na pergunta 3 já aludi ao conhecimento machadiano das questões político-culturais e históricas italianas. Demonstrei como a França aburguesou Shakespeare, diluindo a força das suas obras, adaptadas ao 
neoclassicismo francês, e como a ópera, através do estudo magistral de músicos e libretistas como Giuseppe Verdi e Arigo Boito recuperou filologicamente o texto do bardo inglês e o divulgou para a plateia carioca. Há ainda a defesa da ideia de República que interessa muito aos brasileiros do período e era divulgada pelos jornais italianos.

RA: Você usa como epígrafe do capítulo três uma declaração de Machado, em 1898, na qual ele diz: "Leopardi é um dos santos da minha igreja, pelos versos, pela filosofia, e pode ser que por alguma afinação moral; é provável que também eu tenha a minha corcundinha". Quais outros "santos» pertenceriam, na sua opinião, à «igreja» de Machado, segundo aquilo que podemos depreender da sua obra?

SNS: A lista é imensa. Vai dos clássicos greco-latinos aos clássicos portugueses, e destes aos contemporâneos ingleses, franceses e brasileiros. Citaria José de Alencar, Shakespeare, De Maistre, Baudelaire e Flaubert, os iluministas franceses, os setecentistas ingleses, com Sterne à frente. Mas não me esqueceria de Cervantes, também.

RA: O amor de Machado pela música, pela ópera italiana é um dos assuntos mais reconhecíveis na sua obra, e que demonstram o interesse de um Machado, que não somente recua à história na antiguidade mas participa também das expressões mais notáveis internacionalmente da cultura artística italiana da altura. Você acha que a dimensão politica que umas delas (ópera) iam veiculando seria também uma razão do interesse machadiano?

SNS: Sim. Como já declarei, a ópera era uma das mais modernas e arrebatantes formas de arte do período e envolvia a representação cênica, a música e os temas, sempre escolhidos de acordo com a ordem política do momento. As maravilhosas heroínas escolhidas por Adelaide Ristori (Judith, Medeia, Maria Stuart), dedicadas à boa causa da pátria e do governo, em chave antirromântica, conquistaram os grandes intelectuais brasileiros, como Gonçalves Dias e Machado de Assis. O homem de teatro que foi Machado de Assis não foi indiferente a este fascínio que ele incorporou à estrutura dos seus contos e romances, como procurei provar.

RA: Você tratou da questão da presença e atuação, na Corte e comunidade carioca, dos italianos e de seu papel em trazer ao Brasil a cultura também política italiana: você acha que a o caso italiano, do ponto da sua sofrida história política, seria uma das razões do interesse de Machado pela Itália? Ou prevaleceria o mito ligado ao seu passado, desde a antiguidade clássica?

SNS: Machado tem interesse pelas raízes do humanismo ocidental. Na correspondência com Azeredo da Silveira se refere à Itália como "esse solo tão amassado de história e de poesia". A resposta à pergunta 1 cabe a esta pertinente questão colocada aqui. Gostaria de finalizar esta entrevista, agradecendo muito a quem a formulou, ambas estudiosas ligadas à cultura italiana que puderam 
valorizar um conhecimento comum que nos identifica. Há também no ensaio que dediquei à Machado, uma reflexão teórica quanto à importância dos processos da memória, da busca da identidade e das soluções propostas pela ironia socrática com a qual Machado constrói a parte mais interessante da sua obra. Mas essas questões talvez mereçam um outro espaço em outra ocasião.

RA: Pensando em pesquisas futuras/em futuros pesquisadores, quais "itinerários de leitura" ainda precisariam ser investigados na relação de Machado com autores italianos?

SNS: A minha pesquisa pode ser estendida aos autores espanhóis e portugueses, também. Procurei definir o método de trabalho machadiano e, ao mesmo tempo, fornecer um método crítico de análise, igualmente.

Andréia Guerini Andreia.Guerini@gmail.com

Recebido em: 15 out. 2018 Aceito em: $11 \mathrm{dez} .2018$ Publicado em: 29 dez. 2018 